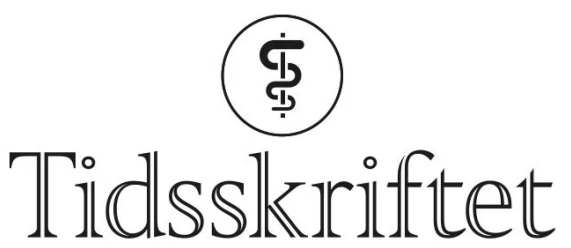

DEN NORSKE LEGEFORENING

\title{
Flere legemidler med antikolinerg virkning
}

KOMMENTAR

\section{$B \varnothing R G E$ LILLEBO}

borge.lillebo@ntnu.no

Børge Lillebo er førsteamanuensis ved NTNU og Konstituert overlege Sykehuset Levanger/HNT. Forfatteren har ikke oppgitt noen interessekonflikter.

Takk til Reiter, Stenberg-Nilsen og Økland for en flott oversikt over legemidler med antikolinerg virkning (1ㅣ). Det finnes noen flere registrerte preparater i Norge med antikolinerg virkning enn de som er nevnt i tabell 1 . Noen brukes i liten grad og andre har først og fremst lokale antikolinerge virkninger (og bivirkninger).

Inhalasjonsmedisinene tiotropium, ipratropium, aklinidium, umeklinidium og glykopyrron vil kunne gi lokale antikolinerge virkninger i munn, luftveier og gastrointestinalkanalen. De har lav systemisk absorpsjon, slik at urinretensjon og akkomodasjonsforstyrrelser er sjelden, men likevel anbefales forsiktighet ved trangvinkelglaukom eller urinretensjon (ㅁ).

Øyedråpene tropikamid, syklopentolat og atropin har først og fremst lokale virkninger i øyet, men kan gi munntørrhet (3). Selv om systemiske bivirkninger kanskje er et mer teoretisk enn et opplevd problem, bør man være oppmerksom på muligheten for bivirkninger hos sårbare pasienter (4).

Antiparkinsonmidlene benztropin og orfenadrin brukes sjelden. De har samme bivirkninger som biperiden som allerede er listet opp i tabell 1.

Atropin, butylskopolamin, glykopyrron og hyoscyamin brukes alle systemisk og gir systemiske virkninger og bivirkninger. Butylskopolamin og glykopyrron passerer i liten grad blod-hjerne-barriæren, men forsiktighet hos eldre er likevel anbefalt (5).

PS! En kunne også diskutere om legemidler med antinikotinerg virkning også burde omtales som antikolinerge, men de har en annen virkning og et veldig avgrenset bruksområde. Et gammelt antinikotinergt legemiddel ble dog forsøkt som blodtrykksmedisin samt brukt for å framprovosere bronkokonstriksjon i et forskningsprosjekt. Det gikk ikke så bra siden forskerne ikke hadde lest godt nok om bivirkningene på forhånd ( $\underline{6})$. Vi får håpe denne artikkelen blir lest av mange i alle fall. 
1. Reiter L, Stenberg-Nilsen H, Økland HG. Bruk av legemidler med antikolinerg virkning hos eldre. Tidsskr Nor Legeforen 2021; 141. doi: 10.4045/tidsskr.20.0775. [PubMed][CrossRef]

2. Norsk legemiddelhåndbok. L1o.2.4 Antikolinergika. https://www.legemiddelhandboka.no/L10.2.4/Antikolinergika

3. Løkken P, Birkeland JM. Medikamenter og munntørrhet. Tidsskr Nor Lægeforen 2005; 125: 581-2. [PubMed]

4. Diamond JP. Systemic adverse effects of topical ophthalmic agents. Implications for older patients. Drugs Aging 1997; 11:352-6o. [PubMed][CrossRef]

5. Norsk legemiddelhåndbok. L12.8.1 Butylskopolamin. https://www.legemiddelhandboka.no/L12.8.1/Butylskopolamin

6. Haraldstad AMB. Litteratursøk - liv eller død? Tidsskr Nor Lægeforen 2002; 122: 942-4. [PubMed]

Publisert: 27. september 2021. Tidsskr Nor Legeforen. DOI: 10.4045/tidsskr.21.0627

(C) Tidsskrift for Den norske legeforening 2023. Lastet ned fra tidsskriftet.no 26. april 2023. 